\title{
Protective Effect of Aged Garlic Extract Against the Oxidative Stress Induced by Acute Ionizing Irradiation on Hepatic Antioxidant Enzymes in Rats
}

\author{
Kouam Foubi Brice Bertrand ${ }^{1}$, Chuisseu Djamen Dieudonné Pascal ${ }^{2}$, \\ Dzeufiet Djomeni Paul Désiré ${ }^{3, "}$, Samba Ngano Odette ${ }^{4}$, Mouelle Sone ${ }^{1}$, \\ Tiedeu Alain Bertin ${ }^{5}$, Gonsu Fotsin Joseph ${ }^{1}$ \\ ${ }^{1}$ Faculty of Medicine and Biomedical Sciences, University of Yaoundé I, Yaoundé, Cameroon \\ ${ }^{2}$ Faculty of Health Sciences, Université des Montagnes, Bangangté, Bangangté, Cameroon \\ ${ }^{3}$ Faculty of Sciences, University of Yaoundé I, Yaoundé, Cameroon \\ ${ }^{4}$ Faculty of Sciences, University of Dschang, Dschang, Cameroon \\ ${ }^{5}$ National Advanced School of Engineering, University of Yaoundé I, Yaoundé, Cameroon
}

\section{Email address:}

dzeufiet@yahoo.fr (D. D. P. Désiré)

*Corresponding author

\section{To cite this article:}

Kouam Foubi Brice Bertrand, Chuisseu Djamen Dieudonné Pascal, Dzeufiet Djomeni Paul Désiré, Samba Ngano Odette, Mouelle Sone, Tiedeu Alain Bertin, Gonsu Fotsin Joseph. Protective Effect of Aged Garlic Extract Against the Oxidative Stress Induced by Acute Ionizing Irradiation on Hepatic Antioxidant Enzymes in Rats. European Journal of Clinical and Biomedical Sciences.

Vol. 2, No. 6, 2016, pp. 69-82. doi: 10.11648/j.ejcbs.20160206.13

Received: October 19, 2016; Accepted: November 11, 2016; Published: December 12, 2016

\begin{abstract}
Ionizing radiations damage cells, tissues and organs among which the liver through a cascade of molecular events that are triggered by reactive oxygen species (ROS), lipid peroxidation and nitrogen species (NS). Aged Garlic Extract (AGE) has been demonstrated to possess free radical scavenging capacity and antioxidant activity. Therefore, the present study has been focused in analyzing the properties of AGE against the lipid peroxidation and oxidative damages of rat liver tissues induced by acute radiation. Eight groups, five healthy male rats each were used (20 irradiated and 20 Sham Irradiated), among which some were receiving via gavages distilled water, the others AGE at different doses $(25 \mathrm{mg} / \mathrm{kg}$ and $50 \mathrm{mg} / \mathrm{kg})$ and the rest vitamin E + Alpha Lipoïc Acid. Then, biochemical analyses, lipid peroxidation, total Protein and antioxidants assessment were made from blood samples and liver tissue homogenates. Exposure of rats to gamma radiation caused a significant increase in the level of Malondialdehyde, Nitrite, transaminase enzymes, alkaline phosphatase, and Bilirubin (Total Serum Bilirubin, Direct Bilirubin and Unconjugated Bilirubin) level while a significant decrease was recorded in serum total proteins, glutathione content, superoxide dismutase, catalase activities and total protein level. AGE treated rats revealed a significant improvement in all previous parameters. From these results, it can be concluded that AGE may have significant anti-radiation properties in rat's liver after radiation exposure.
\end{abstract}

Keywords: Irradiation, Oxidative Stress, AGE, Liver, Antioxidant Enzymes, Rats

\section{Introduction}

Whole body exposure of male rats to gamma radiation increased lipid peroxidation in the liver resulting in biomembrane damage of sub-cellar structures and release of their enzymes. In several studies, a significant increase in lipid peroxidation (LPO) levels was observed in gamma radiated group, whereas a significant decrease in GSH content was recorded in liver of gamma radiated group [1-3]. This is evidenced by increase of Thiobarbituric Acid Reactive Substances (TBARS) in mitochondria, lysosomes and microsomes [4]. Changes in the content of reduced glutathione (GSH), glutathione peroxidase (GSHpx), glucose-6- phosphate dehydrogenase (G-6-PD), superoxide dismutase (SOD) and catalase (CAT) in blood, liver and spleen were also evaluated in different rat groups [2]. 
The first report of the use of chemicals to protect mammals against radiation-induced damage appeared in 1949, when Patt et al. [5] reported that cysteine protected mice and rats against radiation-induced sickness and mortality. Since then, several chemical compounds and their analogues have been screened for their radioprotective effects. However, the practical applicability of the majority of these synthetic compounds has been limited because of toxicity at radioprotective doses [6]. Thus it was considered important to explore alternatives to the synthetic compounds that would be radioprotective at nontoxic doses. Plants have been used to treat various ailments in humans since time immemorial, and herbal preparations have usually been considered safer and less toxic than synthetic compounds. Moreover, phytoconstituents and herbal medicine are important to manage pathological conditions of diseases caused by free radicals [7]. Therefore, it is natural that the choices of alternative radioprotectors include plants and plant products.

Recently, AGE has received particular attention because its radio-protective and anti-oxidative efficacy has been reported [8-10].

ALA and Vitamin E had been reported to have highly protective effect on lipid peroxidation and administration of ALA + Vitamin E had significant protective effect on blood, liver and muscles against oxidative damage [11].

In view of these considerations, the main objective of this study was to assess the role of Aged Garlic Extract against radiation induced oxidative stress associated with some biochemical disorders in male Wistar albino rats livers after total body exposure to acute ionizing irradiation using Vitamin E and Lipoïc Acid as positive control group.

\section{Material and Methods}

\subsection{Animals}

Eighty healthy Albino male rats (Rattus norvegicus) of Wistar strain (3 to 4 months old) ranging from 214-230g body weight were obtained according to the $\mathrm{ICH}$ guidelines from animal lab Université des Montagnes, Bangangté and Douala University in Cameroon. Their acclimatization to laboratory conditions took place at room temperature, relative humidity and natural light-dark cycle (12 hours light and 12 hours dark). The rats were given ad libitum tap water and food of a commercial balanced diet. Five animals were housed per plastic cage containing paddy husk (procured locally) as bedding and fasted night before sacrifice. The experimental protocol and the maintenance of the experimental animals was done in accordance with the regulations of the Organization for Economic Cooperation and Development (OECD) guide since in Cameroon the ethics committee focuses only on clinical studies.

\subsection{Chemical}

Aged Garlic Extract (KYOLIC ${ }^{\circledR}$ Aged Garlic Extract ${ }^{\text {TM }}$ Liquid) is prepared by soaking sliced raw garlic (Allium sativum Linn) with a quality plan program (QPP-003) in 15$20 \%$ aqueous ethanol for 20 months at room temperature. The extract is then filtered and concentrated under reduced pressure according to the guidelines of Good Manufacturing practices established by the World Health Organization. The garlic is grown under strictly controlled organic conditions (without herbicides or pesticides of any kind), harvested at full maturity, cleaned, sliced and stored in stainless steel tanks under carefully controlled conditions without the use of a heating process [12-14]. The content of water-soluble compounds is relatively high whereas that of oil-soluble compounds is relatively low [14]. The AGE used in this study is standardized with S-Allyl Cysteine and contained $30 \%$ extracted solids $(300 \mathrm{mg} / \mathrm{ml})$, and S-allyl cysteine present at $1.47 \mathrm{mg} / \mathrm{ml}$.

\subsection{Experimental Design}

Two weeks after acclimatization and conditioning, the animals were randomly divided into four equal and double male rat groups in separate plastic cages, five rats each. Two negative control groups receiving $10 \mathrm{~mL} / \mathrm{kg}$ of distilled water (I and II), two AGE-treated groups at dose of $25 \mathrm{mg} / \mathrm{kg} \mathrm{AGE}$ (IIII and IV), two AGE-treated groups at dose of $50 \mathrm{mg} / \mathrm{kg}$ AGE (V and VI) and two positive control groups (receiving $50 \mathrm{mg} / \mathrm{kg}$ Vitamin $+25 \mathrm{mg} / \mathrm{kg}$ of Lipoïc Acid) (VII and VIII) were used. Among the double groups, 20 were irradiated (rats of groups II, IV, VI and VIII) and 20 sham irradiated (rats of groups I, III, V and VII). The rats of each group were fed via gavages one hour after irradiation on day 1 and for 7 consecutive days and weighed daily during the experiment. The experimental protocol and the maintenance of the experimental animals was done in accordance with the standard ethical guidelines for laboratory animal use and care as described in the European Community guidelines; EEC Directive $86 / 609 /$ EEC, of the $24^{\text {th }}$ November 1986 [15].

\subsection{Irradiation}

The Albino Wistar rats were placed in collective cages made of plastic for whole-body exposure after at least two weeks of acclimatization and conditioning. Rats were exposed using the facilities provided by the Oncology and Radiotherapy department of the Douala General Hospital. Irradiation was delivered by an ALCYON-II model cobalt-60 teletherapy unit (General Electric/GE Healthcare). The rats in an area of $36 \times 36 \mathrm{~cm}$ were exposed to a single dose of 4.5 Gy applied as single shot dose at a dose rate of $0.55 \mathrm{~Gy} / \mathrm{min}$. Five animals were irradiated at once and sham-irradiated animals were treated in the same manner but were not exposed to the source. After irradiation, the rats were brought back to the animal Lab of Douala University for the follow up and the tests.

\subsection{Sample Collection}

\subsubsection{Blood Samples}

The animals were put to fast during the night before their blood test $\left(7^{\text {th }}\right.$ day post irradiation). The day of sacrifice $\left(8^{\text {th }}\right.$ 
day post irradiation), arterio-venous blood was collected in dry tubes and allowed to clot (stand for $30 \mathrm{~min}$ ) and centrifuged at $3000 \mathrm{rpm}$ for $15 \mathrm{~min}$. The supernatant (serum) obtained was gathered in Eppendorf tubes and stored at $20^{\circ} \mathrm{C}$ for biochemical analysis of alkaline phosphatase, transaminase enzymes (Aspartate transaminase and Alanine transaminase), Bilirubin (Total Serum Bilirubin and Direct Bilirubin) and Total proteins.

\subsubsection{Tissue Samples}

A vertical midline thoracic and abdominal incision was done to explore the rat's viscera. Because of administration of distilled water, AGE, Lipoïc acid + vitamin $\mathrm{E}$ for consecutive days and whole body irradiation at $4.5 \mathrm{~Gy}$, liver of each rat was excised, cleaned from their surrounding fat and connective tissue, washed with normal saline, blotted with filter paper, examined macroscopically (form modification, size, consistency and color) and weighed.

\subsection{Biochemical Assay}

Liver biomarkers assessment: the levels of aspartate transaminase (AST) and alanine transaminase (ALT) enzymes were estimated in the sera of the blood samples using commercial kits (Inmesco GmbH - Wiedtalstrasse 11\&18-D53577 Neustadt/Wied-Germany) according to Kaplan [16] and alkaline phosphatase level estimated in accordance with Prahlad and Conaway method [17]. Also, serum total protein was determined using Biuret reaction [18] and Bilirubin was assayed according to calculation (Unconjugated Bilirubin) and the method of Balistreri and Shaw (Total Serum Bilirubin and Direct Bilirubin) [19] as well.

Lipid peroxidation, total Protein and antioxidants assessment in tissue homogenates: Homogenate 20\% was prepared by adding $2 \mathrm{~mL}$ of $50 \mathrm{mM}$, Tris- $\mathrm{HCl}$ buffer to 0.40 $\mathrm{g}$ of liver. Homogenate obtained was centrifuged at $3500 \mathrm{rpm}$ for 25 minutes at $4{ }^{\circ} \mathrm{C}$ after grinding in a mortar on ice tray. The supernatants were collected for the measurement of catalase (CAT), superoxide dismutase (SOD), Nitrite $\left(\mathrm{N}^{2-}\right)$, total proteins, the levels of reduced glutathione (GSH), and malondialdehyde (MDA). GSH was determined in accordance with the method of Ellman [20] and SOD activity according to the method of Misra and Fridovish [21]. CAT activity was estimated by measuring the decomposition of hydrogen peroxide, according to the method of Sinha [22] and Nitrite assay according to Slack [23]. The marker of lipid peroxidation (MDA) was determined according to the method of Wilbur et al. [24].

\subsection{Statistical Analyses}

Results were expressed as mean \pm Standard Error of the Mean (SEM). Comparison of means was done by Dunnett test as post hoc test. $\mathrm{P}$ values less than 0.05 were considered statistically significant. Statistical evaluation was conducted using one way analysis of variance (ANOVA) software Graph Pad Prism 5.03. With the $\alpha$ risk of 5\%, statistically significant differences are reported in the tables and figures with an asterisk $(*)$, the highly statistically significant differences are marked with two stars $(* *)$ and statistically highly significant differences are indicated by three stars $(* * *)$.

\section{Results}

\subsection{Liver Biomarkers of Rats}

\subsubsection{Effect of $\gamma$-Radiation and AGE Administration on Protein Profile}

From Figure 1, it is clear that irradiation caused a significant increase $(\mathrm{P}<0.001)$ in serum total protein of about $39.64 \% 12.20 \pm 0.2 \mathrm{Vs} 8.74 \pm 0.42 \mathrm{mg} / \mathrm{dL}$ ) in the group "Irradiation $+25 \mathrm{mg} / \mathrm{kg} \mathrm{AGE"} \mathrm{and} \mathrm{a} \mathrm{significant} \mathrm{drop}(\mathrm{P}<$ $0.001)$ in the range of $56.03 \%(3.84 \pm 0.26 \mathrm{Vs} 8.74 \pm 0.42$ $\mathrm{mg} / \mathrm{dL})$ and $2.93 \%(6.18 \pm 0.26 \mathrm{Vs} 8.74 \pm 0.42 \mathrm{mg} / \mathrm{dL})$ in groups "Irradiation + Distilled Water" and "Irradiation + Vitamin E and Lipoïc Acid" compared to the negative control group ("Sham Irradiation + Distilled Water"). Among the irradiated groups, a significant increase $(\mathrm{P}<$ 0.001 ) in serum protein was observed in the groups "Irradiation $+25 \mathrm{mg} / \mathrm{kg} \mathrm{AGE"} \mathrm{and} \mathrm{"Irradiation}+50 \mathrm{mg} /$ $\mathrm{kg}$ AGE" respectively, in order of $217.60 \%(12.20 \pm 0.2 \mathrm{Vs}$ $3.84 \pm 0.26 \mathrm{mg} / \mathrm{dL})$ and $154.82 \%(9.79 \pm 0.06 \mathrm{Vs} 3.84 \pm 0.26$ $\mathrm{mg} / \mathrm{dL})$. In addition, compared to the positive control group ("Irradiation + Vitamin E and Lipoïc Acid"), a significant increase $(\mathrm{P}<0.001)$ in serum proteins was observed in the the group "Irradiation $+25 \mathrm{mg} / \mathrm{kg} \mathrm{AGE"} \mathrm{in} \mathrm{order} \mathrm{of}$ $97.38 \%(12.20 \pm 0.2 \mathrm{Vs} 6.18 \pm 0.26 \mathrm{mg} / \mathrm{dL})$ and of $58.36 \%$ $(9.79 \pm 0.06 \mathrm{Vs} 6.18 \pm 0.26 \mathrm{mg} / \mathrm{dL})$ in those of the group "Irradiation + $50 \mathrm{mg} / \mathrm{kg}$ AGE".

\section{Total Proteins dosage in serum}

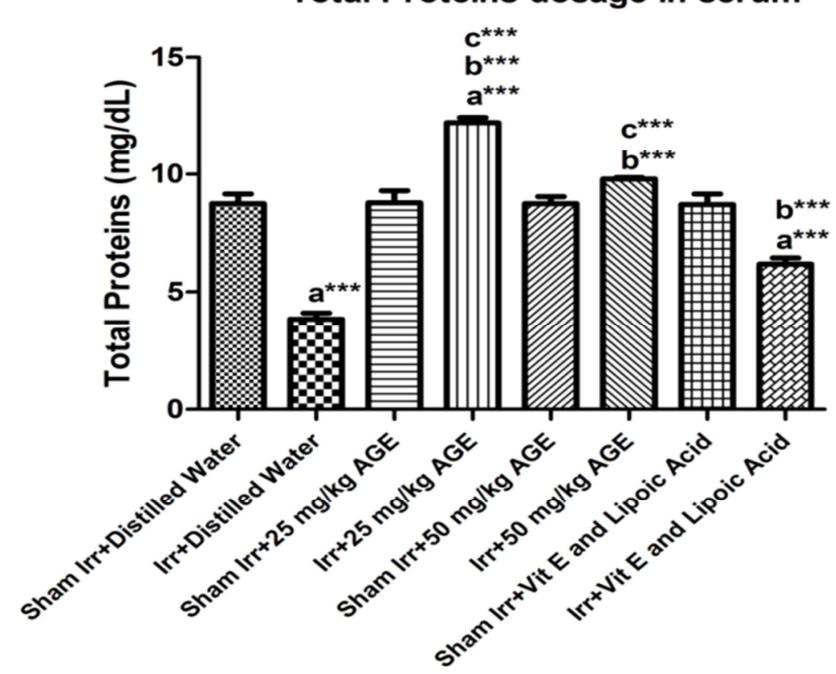

Figure 1. Effects of $\gamma$-radiation and AGE on serum total protein.

Each bar represents the Mean \pm ESM, $(n=5$ : number of animals in each group). Significant differences are:

- $\mathrm{a} * \mathrm{P}<0.05 ; \mathrm{a} * * \mathrm{P}<0.01 ; \mathrm{a}^{* * * \mathrm{P}}<0.001$ : when comparing groups to control ("Sham Irradiation + Distilled Water") (a) or.

- $\mathrm{b}^{* \mathrm{P}}<0.05 ; \mathrm{b}^{* * \mathrm{P}}<0.01 ; \mathrm{b}^{* * * \mathrm{P}}<0.001$ : when comparing groups to "Irradiation + Distilled Water Group" (b) or. 
- $\mathrm{c}^{* \mathrm{P}}<0.05 ; \mathrm{c} * * \mathrm{P}<0.01 ; \mathrm{c}^{* * * \mathrm{P}}<0.001:$ when comparing groups to "Irradiation+Vitamin E and Lipoïc Acid Group" (c).

\subsubsection{Alanine Transaminase (ALT)}

The levels of alanine transaminase increased significantly after irradiation, $(\mathrm{p}<0.001)$ in order of $52.8 \%$ $(114.6 \pm 3.97 \mathrm{Vs} 75 \pm 4.44 \mathrm{U} / \mathrm{L})$ in the "Irradiation + Distilled Water" group and decreased significantly $(\mathrm{p}<0.001$ and $\mathrm{p}$ $<0.01)$ in the range of $57.33 \%(32.0 \pm 2.17 \mathrm{Vs} 75 \pm 4.44 \mathrm{U} / \mathrm{L})$ and $37.87 \%(46.6 \pm 3.06 \mathrm{Vs} 75 \pm 4.44 \mathrm{U} / \mathrm{L})$ in the groups "irradiation + $25 \mathrm{mg} / \mathrm{kg}$ AGE "and" irradiation + $50 \mathrm{mg} /$ kg AGE". Compared to the group "Irradiation + Distilled Water", the decrease of this rate was significant $(\mathrm{p}<0.001)$ in the range of $72.08 \%(32.0 \pm 2.17 \mathrm{Vs} 114.6 \pm 3.97 \mathrm{U} / \mathrm{L})$ and $59.34 \%(46.6 \pm 3.06 \mathrm{Vs} 114.6 \pm 3.97 \mathrm{U} / \mathrm{L})$ in the groups "Irradiation + $25 \mathrm{mg} / \mathrm{kg} \mathrm{AGE"} \mathrm{and} \mathrm{"Irradiation}+50 \mathrm{mg} /$ $\mathrm{kg}$ AGE". This reduction remained significant in order of $43.06 \%(32.0 \pm 2.17 \mathrm{Vs} 56.2 \pm 3.25 \mathrm{U} / \mathrm{L})$ in the group "Irradiation + $25 \mathrm{mg} / \mathrm{kg}$ AGE" compared to the positive control group "Irradiation + Vitamin E and Lipoïc Acid" (Figure 2).

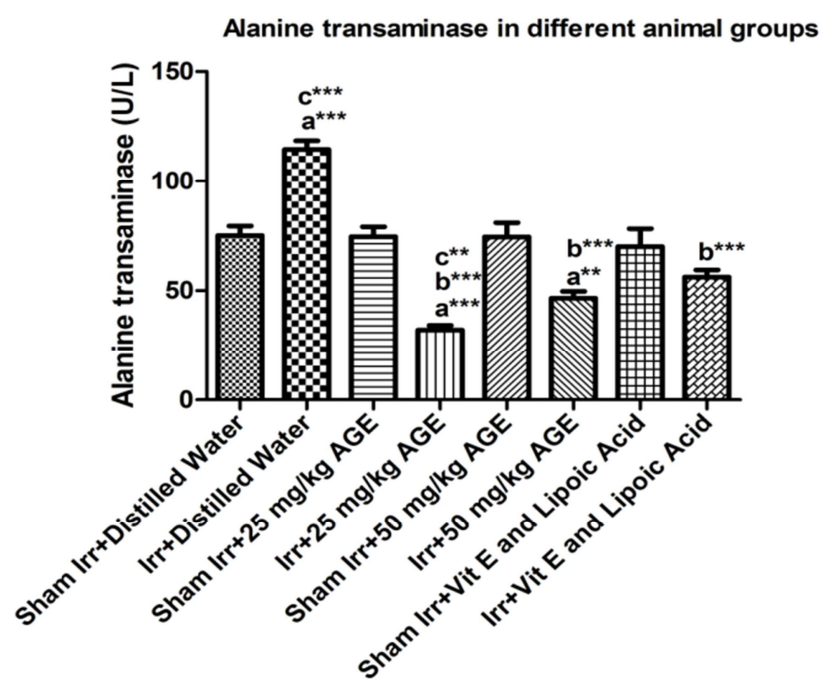

Figure 2. Effects of $\gamma$-radiation and AGE on Alanine transaminase rate.

Each bar represents the Mean $\pm E S M$, ( $n=5$ : number of animals in each group). Significant differences are:

- $\mathrm{a} * \mathrm{P}<0.05 ; \mathrm{a}^{* * \mathrm{P}}<0.01 ; \mathrm{a}^{* * * \mathrm{P}}<0.001$ : when comparing groups to control ("Sham Irradiation + Distilled Water") (a) or

- $\mathrm{b}^{* \mathrm{P}}<0.05 ; \mathrm{b} * * \mathrm{P}<0.01 ; \mathrm{b}^{* * * \mathrm{P}}<0.001$ : when comparing groups to "Irradiation+Distilled Water Group" (b) or

- $\mathrm{c}^{* \mathrm{P}}<0.05 ; \mathrm{c} * * \mathrm{P}<0.01 ; \mathrm{c}^{* * * \mathrm{P}}<0.001$ : when comparing groups to "Irradiation+Vitamin E and Lipoïc Acid Group" (c).

\subsubsection{Aspartate Transaminase (AST)}

The irradiation resulted in a significant increase $(\mathrm{p}<0.01)$ of aspartate transaminase in the group "Irradiation + Distilled Water" in order of $38.08 \%(190.0 \pm 8.15 \mathrm{Vs} 137.6 \pm 7.19 \mathrm{U} / \mathrm{L})$ and a significant reduction in the group "Irradiation $+25 \mathrm{mg}$ $/ \mathrm{kg} \mathrm{AGE"}(\mathrm{p}<0.001)$ in the range of $44.33 \%(76.6 \pm 6.72 \mathrm{Vs}$ $137.6 \pm 7.19 \mathrm{U} / \mathrm{L})$. Animals receiving AGE at doses of 25 and $50 \mathrm{mg} / \mathrm{kg}$, showed a significant decrease $(\mathrm{P}<0.001)$, in aspartate transaminase levels compared to the group "Irradiation + Distilled Water "(Figure 3). This decrease is respectively in order of $59.68 \%$, $(76.6 \pm 6.72 \mathrm{Vs} 190.0 \pm 8.15$ $\mathrm{U} / \mathrm{L})$ and $43.79 \% \quad(106.8 \pm 8.32 \quad$ Vs $190.0 \pm 8.15 \quad \mathrm{U} / \mathrm{L})$. Similarly, compared to the group "Irradiation + Vitamin E and Lipoïc Acid" a significant decrease $(\mathrm{p}<0.01)$ was observed in the group "Irradiation $+25 \mathrm{mg} / \mathrm{kg} \mathrm{AGE"} \mathrm{in}$ order of $34.97 \%(76.6 \pm 6.72 \mathrm{Vs} 117.8 \pm 7.96 \mathrm{U} / \mathrm{L})$ and a nonsignificant decline $(\mathrm{P}>0.05)$ in the group "Irradiation +50 $\mathrm{mg} / \mathrm{kg}$ AGE" in order of $9.34 \%$ (106.8 $\pm 8.32 \mathrm{Vs} 117.8 \pm 7.96$ $\mathrm{U} / \mathrm{L})$.

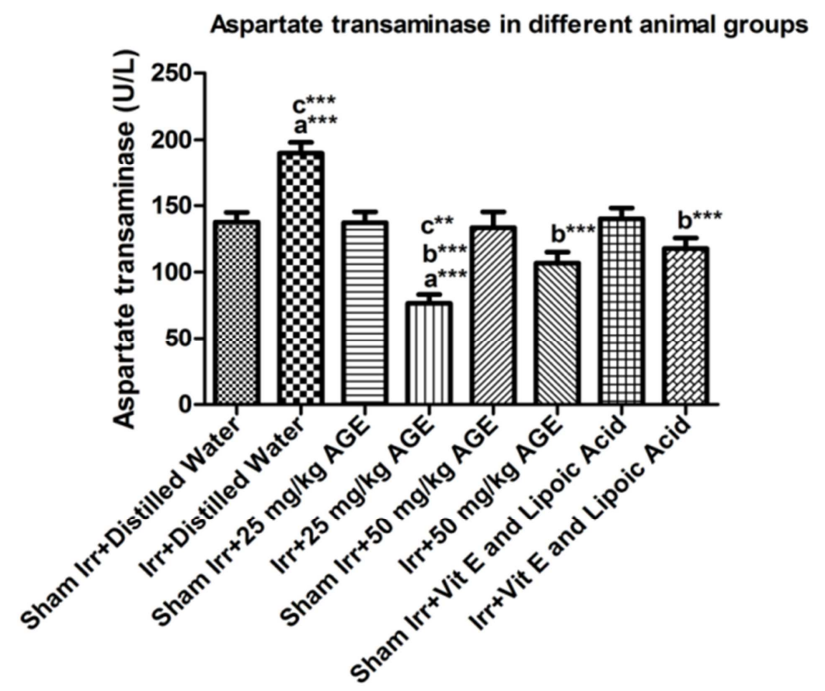

Figure 3. Effects of $\gamma$-radiation and AGE on Aspartate transaminase rate.

Each bar represents the Mean $\pm E S M$, ( $n=5$ : number of animals in each group). Significant differences are:

- $\mathrm{a}^{* \mathrm{P}}<0.05 ; \mathrm{a} * * \mathrm{P}<0.01 ; \mathrm{a}^{* * * \mathrm{P}}<0.001$ : when comparing groups to control ("Sham Irradiation + Distilled Water") (a) or.

- $\mathrm{b}^{* \mathrm{P}}<0.05 ; \mathrm{b} * * \mathrm{P}<0.01 ; \mathrm{b}^{* * * \mathrm{P}}<0.001$ : when comparing groups to "Irradiation+Distilled Water Group" (b) or.

- $\mathrm{c}^{* \mathrm{P}}<0.05 ; \mathrm{c} * * \mathrm{P}<0.01 ; \mathrm{c}^{* * * \mathrm{P}}<0.001$ : when comparing groups to "Irradiation+Vitamin E and Lipoïc Acid Group" (c).

\subsubsection{Alkaline Phosphatase (ALP)}

Figure 4 reveals that alkaline phosphatase increased significantly $(\mathrm{p}<0.001)$ in the group "Irradiation + Distilled Water" in order of $36.4 \%(68.2 \pm 1.32 \mathrm{Vs} 50.00 \pm 1.10 \mathrm{U} / \mathrm{L})$ and significantly decreased $(\mathrm{p}<0.001)$ in the groups "Irradiation + $25 \mathrm{mg} / \mathrm{kg} \mathrm{AGE"} \mathrm{and} \mathrm{"Irradiation} \mathrm{+} 50 \mathrm{mg} / \mathrm{kg} \mathrm{AGE"} \mathrm{in} \mathrm{the}$ range of $42.8 \%(28.6 \pm 1.08 \mathrm{Vs} 50.00 \pm 1.10 \mathrm{U} / \mathrm{L})$ and $24 \%$ $(38 . \pm 1.67 \mathrm{Vs} 50.00 \pm 1.10 \mathrm{U} / \mathrm{L})$. Compared to the group "Irradiation + Distilled Water", Figure 4 shows a significant decrease $(p<0.001)$ in the rate of alkaline phosphatase in 
order of $58.06 \%(28.6 \pm 1.08 \mathrm{Vs} 68.2 \pm 1.32 \mathrm{U} / \mathrm{L})$ and $44.28 \%$ $(38 . \pm 1.67 \mathrm{Vs} 68.2 \pm 1.32 \mathrm{U} / \mathrm{L})$ in the groups receiving AGE at doses of 25 and $50 \mathrm{mg} / \mathrm{kg}$. Compared to the positive control group "Irradiation + Vitamin E and Lipoïc Acid", the decline was significant $(\mathrm{p}<0.001)$ in the groups "Irradiation $+25 \mathrm{mg} /$ $\mathrm{kg}$ AGE" in order of 46.64\% (28.6 $\pm 1.08 \mathrm{Vs} 53.6 \pm 3.17 \mathrm{U} / \mathrm{L})$ and "Irradiation $+50 \mathrm{mg} / \mathrm{kg}$ AGE» in order of $29.10 \%$ $(38 . \pm 1.67$ Vs $53.6 \pm 3.17 \mathrm{U} / \mathrm{L})$.

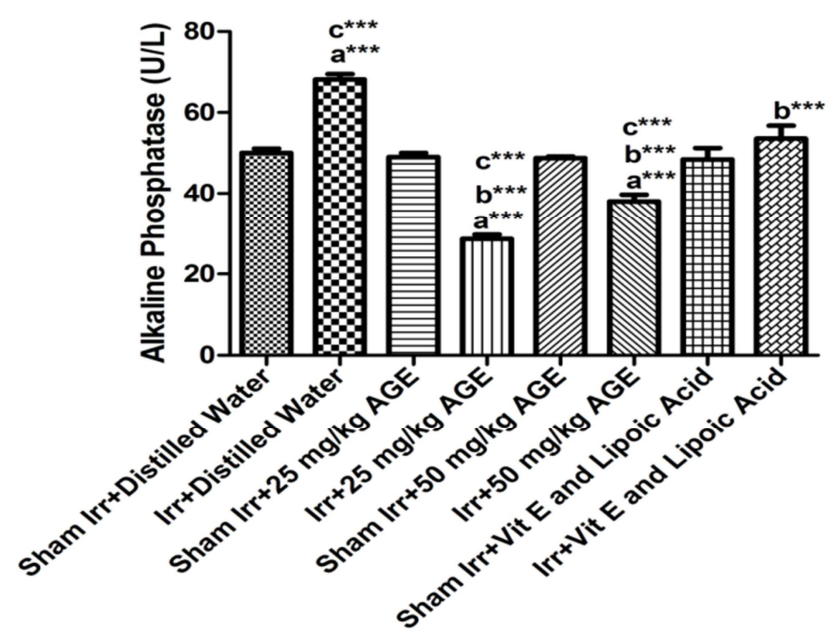

Figure 4. Effects of $\gamma$-radiation and AGE on alkaline phosphatase rate.

Each bar represents the Mean $\pm E S M$, ( $n=5$ : number of animals in each group). Significant differences are:

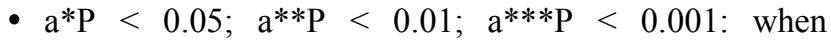
comparing groups to control ("Sham Irradiation + Distilled Water") (a) or.

- $\mathrm{b}^{* \mathrm{P}}<0.05 ; \mathrm{b} * * \mathrm{P}<0.01 ; \mathrm{b}^{* * * \mathrm{P}}<0.001$ : when comparing groups to "Irradiation+Distilled Water Group" (b) or.

- $\mathrm{c} * \mathrm{P}<0.05 ; \mathrm{c}^{* * \mathrm{P}}<0.01 ; \mathrm{c} * * * \mathrm{P}<0.001$ : when comparing groups to "Irradiation+Vitamin E and Lipoïc Acid Group" (c).

\subsubsection{Bilirubin}

\section{i. Bilirubin Total}

After irradiation, Figure 5 shows a significant increase $(\mathrm{P}$ $<0.001$ ) of total Bilirubin level in animals of group "Irradiation + Distilled Water" in order of 52.84\% (2.79 \pm 0.25 Vs $1.83 \pm 0.18 \mathrm{mg} / \mathrm{dL})$, similarly a significant decrease $(\mathrm{P}<$ 0.001 and $\mathrm{P}<0.05)$ in the range of $76.59 \%(0.43 \pm 0.08 \mathrm{Vs}$ $1.83 \pm 0.18 \mathrm{mg} / \mathrm{dL})$ and $42.89 \%(1.04 \pm 0.15 \mathrm{Vs} 1.83 \pm 0.18$ $\mathrm{mg} / \mathrm{dL})$ in groups treated with AGE at a dose of 25 and 50 $\mathrm{mg} / \mathrm{kg}$. Moreover, this rate decreased significantly $(\mathrm{P}<$ $0.001)$ in the range of $84.68 \%(0.43 \pm 0.08 \mathrm{Vs} 2.79 \pm 0.25$ $\mathrm{mg} / \mathrm{dL})$ and $62.63 \%(1.04 \pm 0.15 \mathrm{Vs} 2.79 \pm 0.25 \mathrm{mg} / \mathrm{dL})$ in groups "Irradiation $+25 \mathrm{mg} / \mathrm{kg} \mathrm{AGE"} \mathrm{and} \mathrm{"Irradiation}+50$ $\mathrm{mg} / \mathrm{kg}$ AGE" compared to the group "Irradiation + Distilled Water". The total Bilirubin levels also decreased significantly $(\mathrm{P}<0.01)$ in the groups "Irradiation $+25 \mathrm{mg} / \mathrm{kg} \mathrm{AGE"} \mathrm{and}$ not significantly $(\mathrm{P}>0.05)$ in the group "Irradiation $+50 \mathrm{mg}$ / $\mathrm{kg}$ AGE" respectively in order of $68.53 \%(0.43 \pm 0.08 \mathrm{Vs}$ $1.36 \pm 0.11 \mathrm{mg} / \mathrm{dL})$ and $23.24 \%(1.04 \pm 0.15 \mathrm{Vs} 1.36 \pm 0.11$ $\mathrm{mg} / \mathrm{dL}$ ) compared to the positive control "Irradiation + Vitamin E and Lipoïc Acid."

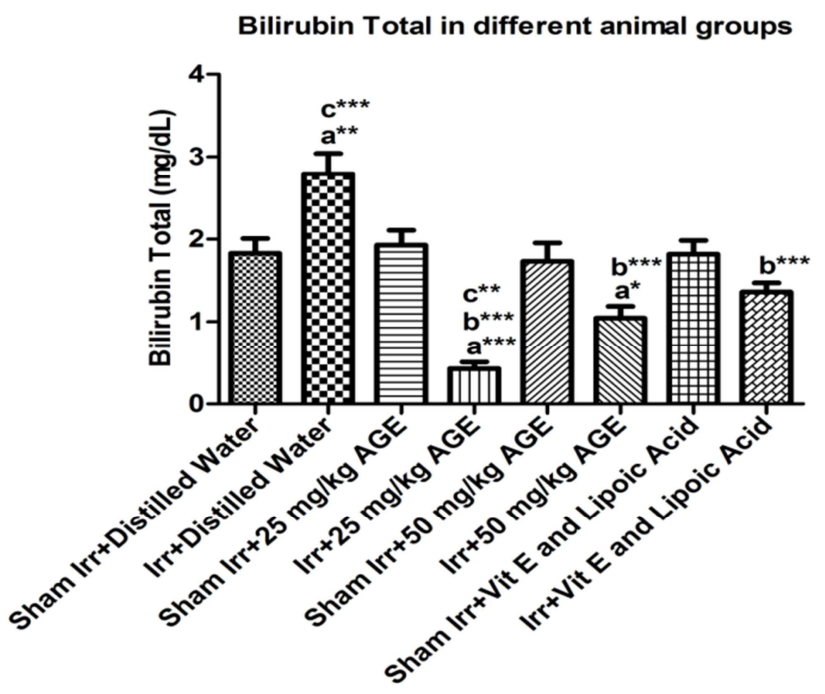

Figure 5. Effects of $\gamma$-radiation and AGE on total bilirubin rate.

Each bar represents the Mean \pm ESM, $(n=5$ : number of animals in each group). Significant differences are:

- $\mathrm{a}^{* \mathrm{P}}<0.05 ; \mathrm{a} * \mathrm{P}<0.01 ; \mathrm{a}^{* * * \mathrm{P}}<0.001$ : when comparing groups to control ("Sham Irradiation + Distilled Water") (a) or.

- $\mathrm{b}^{* \mathrm{P}}<0.05 ;$ b**P $<0.01 ; \mathrm{b}^{* * * \mathrm{P}}<0.001$ : when comparing groups to "Irradiation+Distilled Water Group" (b) or.

- $\mathrm{c} * \mathrm{P}<0.05 ; \mathrm{c} * * \mathrm{P}<0.01 ; \mathrm{c}^{* * * \mathrm{P}}<0.001$ : when comparing groups to "Irradiation+Vitamin E and Lipoïc Acid Group" (c).

\section{ii. Direct Bilirubin}

Figure 6 shows the effect of irradiation and AGE intake on direct Bilirubin. Compared to the negative control group, irradiation resulted in a significant increase of direct Bilirubin level $(\mathrm{P}<0.01)$ in the range of $73.17 \%(0.85 \pm 0.04$ Vs $0.49 \pm 0.08 \mathrm{mg} / \mathrm{dL})$ in the group "Irradiation + Distilled Water "and a significant decrease $(\mathrm{P}<0.01)$ in the range of $70.73 \%(0.14 \pm 0.01 \mathrm{Vs} \quad 0.49 \pm 0.08 \mathrm{mg} / \mathrm{dL})$ and a nonsignificant drop $(\mathrm{P}>0.05)$ in the range of $36.18 \%$ $(0.31 \pm 0.07 \mathrm{Vs} 0.49 \pm 0.08 \mathrm{mg} / \mathrm{dL})$ in the groups "Irradiation $+25 \mathrm{mg} / \mathrm{kg} \mathrm{AGE"} \mathrm{and} \mathrm{"Irradiation} \mathrm{+} 50 \mathrm{mg} / \mathrm{kg} \mathrm{AGE".} \mathrm{A}$ significant decrease $(\mathrm{P}<0.001)$ in the ranges of $83.10 \%$ $(0.14 \pm 0.01 \mathrm{Vs} 0.85 \pm 0.04 \mathrm{mg} / \mathrm{dL})$ and $63.15 \%(0.31 \pm 0.07$ Vs $0.85 \pm 0.04 \mathrm{mg} / \mathrm{dL}$ ) occurred by comparing groups "Irradiation + $25 \mathrm{mg} / \mathrm{kg} \mathrm{AGE"} \mathrm{and} \mathrm{"Irradiation} \mathrm{+} 50 \mathrm{mg} /$ kg AGE" with the group "Irradiation + Distilled Water". The decrease in direct Bilirubin was significant $(\mathrm{P}<0.001)$ in the group "Irradiation $+25 \mathrm{mg} / \mathrm{kg} \mathrm{AGE"} \mathrm{in} \mathrm{order} \mathrm{of}$ $64.88 \% \quad(0.14 \pm 0.01 \quad \mathrm{Vs} \quad 0.41 \pm 0.04 \mathrm{mg} / \mathrm{dL})$ and not significant $(\mathrm{P}>0.05)$ in the group "Irradiation $+50 \mathrm{mg} / \mathrm{kg}$ AGE" in order of $23.41 \%(0.31 \pm 0.07 \mathrm{Vs} 0.41 \pm 0.04 \mathrm{mg} / \mathrm{dL})$ compared to the positive control group "Irradiation + Vitamin E and Lipoïc Acid." 


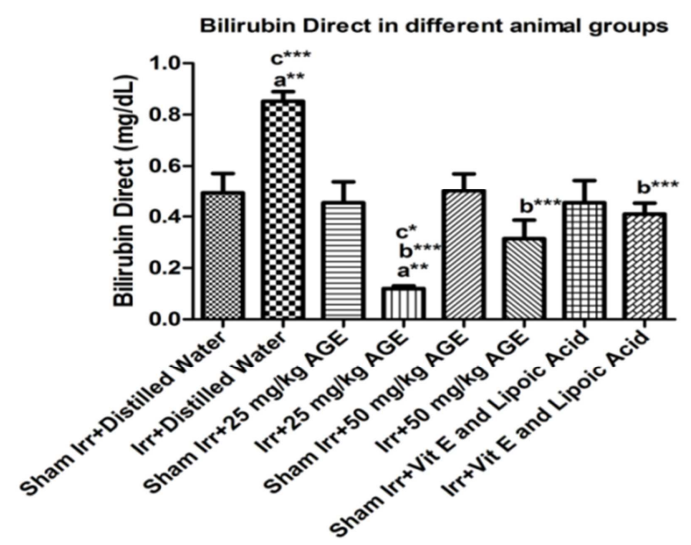

Figure 6. Effects of $\gamma$-radiation and AGE on direct bilirubin rate.

Each bar represents the Mean \pm ESM, $(n=5$ : number of animals in each group). Significant differences are:

- $\mathrm{a}^{* \mathrm{P}}<0.05 ; \mathrm{a} * * \mathrm{P}<0.01 ; \mathrm{a}^{* * * \mathrm{P}}<0.001$ : when comparing groups to control ("Sham Irradiation + Distilled Water") (a) or.

- $\mathrm{b}^{* \mathrm{P}}<0.05 ; \mathrm{b} * * \mathrm{P}<0.01 ; \mathrm{b}^{* * * \mathrm{P}}<0.001$ : when comparing groups to "Irradiation+Distilled Water Group" (b) or.

- $\mathrm{c}^{* \mathrm{P}}<0.05 ; \mathrm{c}^{* * \mathrm{P}}<0.01 ; \mathrm{c}^{* * * \mathrm{P}}<0.001$ : when comparing groups to "Irradiation+Vitamin E and Lipoïc Acid Group" (c).

iii. Unconjugated Bilirubin

Figure 7 shows the effect of irradiation and AGE intake on the direct Bilirubin. Indeed, compared to the negative control "Sham Irradiation + Distilled Water" a non-significant increase $(\mathrm{P}>0.05)$ was observed in the group "Irradiation + Distilled Water" in order of $45.36 \%(1.94 \pm 0.24 \mathrm{Vs} 1.34 \pm 0.24 \mathrm{mg} / \mathrm{dL})$; and a significant decrease $(\mathrm{P}<0.01)$ in the range of $76.95 \%$ $(0.31 \pm 0.08 \mathrm{Vs} 1.34 \pm 0.24 \mathrm{mg} / \mathrm{dL})$ in the irradiated group receiving AGE at a dose of $25 \mathrm{mg} / \mathrm{kg}$. The comparison of groups "Irradiation + $25 \mathrm{mg} / \mathrm{kg}$ AGE" and "Irradiation + $50 \mathrm{mg}$ / kg AGE" with "Irradiation + Distilled Water" group shows a significant decrease $(\mathrm{P}<0.001)$ in the range of $84.14 \%$
$(0.31 \pm 0.08 \mathrm{Vs} 1.94 \pm 0.24 \mathrm{mg} / \mathrm{dL})$ and $62.41 \%(0.73 \pm 0.14 \mathrm{Vs}$ $1.94 \pm 0.24)$ in these groups. This decline remains not significant $(\mathrm{P}>0.05)$ when comparing the groups "Irradiation $+25 \mathrm{mg} / \mathrm{kg}$ AGE" and "Irradiation + $50 \mathrm{mg} / \mathrm{kg}$ AGE" with the group "Irradiation + Vitamin E and Lipoïc Acid" respectively in order of $67.58 \%(0.31 \pm 0.08 \mathrm{Vs} \quad 0.95 \pm 0.11 \mathrm{mg} / \mathrm{dL})$ and $23.16 \%$ $(0.73 \pm 0.14 \mathrm{Vs} 0.95 \pm 0.11 \mathrm{mg} / \mathrm{dL})$.

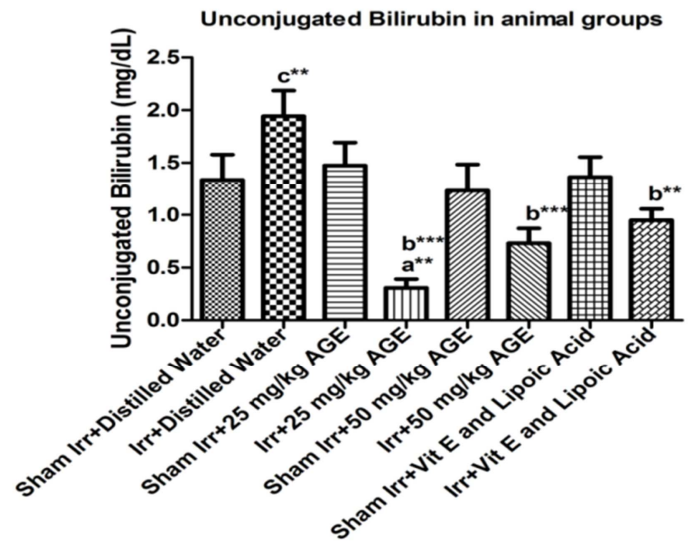

Figure 7. Effects of $\gamma$-radiation and AGE on unconjugated bilirubin rate.

Each bar represents the Mean \pm ESM, $(n=5$ : number of animals in each group). Significant differences are:

- $\mathrm{a} * \mathrm{P}<0.05 ; \mathrm{a} * * \mathrm{P}<0.01 ; \mathrm{a}^{* * * \mathrm{P}}<0.001$ : when comparing groups to control ("Sham Irradiation + Distilled Water") (a) or.

- $\mathrm{b}^{* \mathrm{P}}<0.05 ; \mathrm{b}^{* * \mathrm{P}}<0.01 ; \mathrm{b}^{* * * \mathrm{P}}<0.001$ : when comparing groups to "Irradiation+Distilled Water Group" (b) or.

- $\mathrm{c}^{* \mathrm{P}}<0.05 ; \mathrm{c} * * \mathrm{P}<0.01 ; \mathrm{c}^{* * * \mathrm{P}}<0.001$ : when comparing groups to "Irradiation+Vitamin E and Lipoïc Acid Group" (c).

\subsection{Antioxidants and Lipid Peroxidation}

The different effects of $\gamma$-radiation and AGE are represented in this table below.

Table 1. Effects of $\gamma$-radiation and AGE on oxydative stress marker.

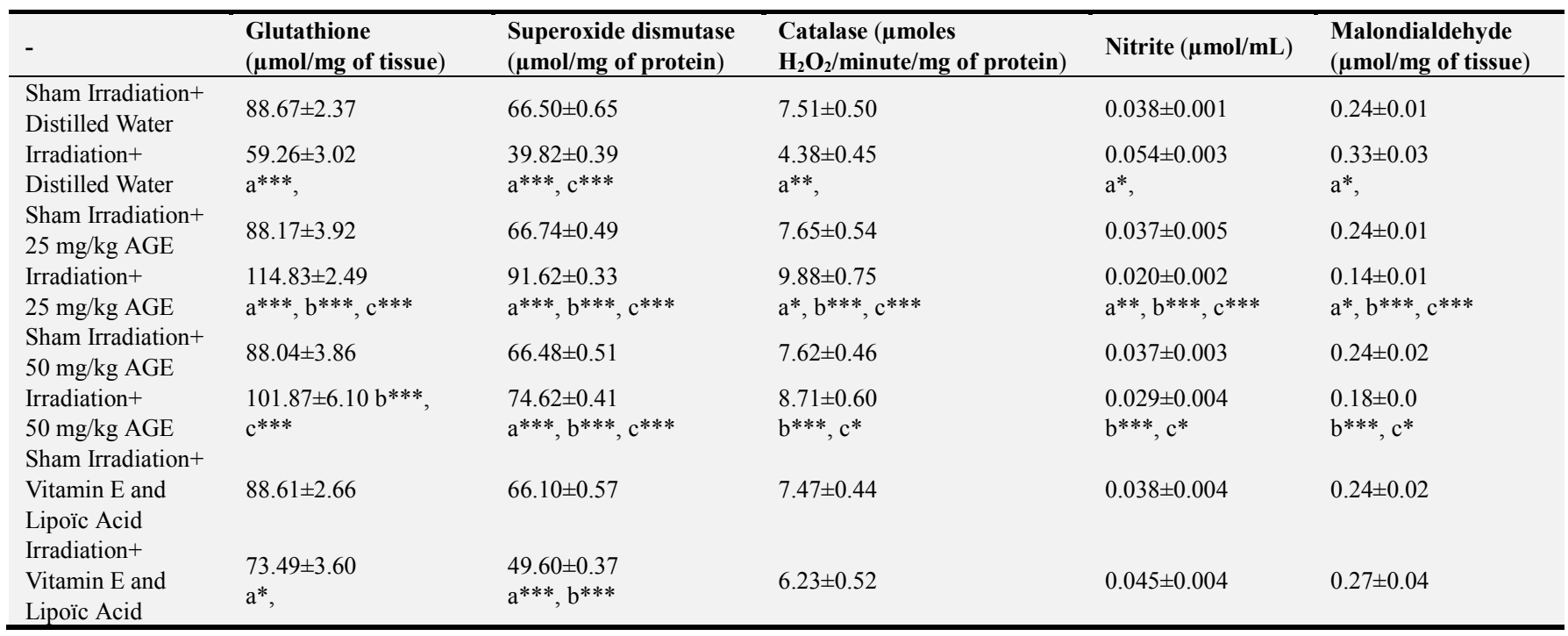


Data are expressed as mean $\pm \operatorname{SEM}(n=5$ : number of animals in each group). Significant differences are:

- $\mathrm{a}^{* \mathrm{P}}<0.05 ; \mathrm{a} * * \mathrm{P}<0.01 ; \mathrm{a}^{* * * \mathrm{P}}<0.001$ : when comparing groups to control ("Sham Irradiation + Distilled Water") (a) or.

- $\mathrm{b}^{* \mathrm{P}}<0.05 ; \mathrm{b} * * \mathrm{P}<0.01 ; \mathrm{b}^{* * * \mathrm{P}}<0.001$ : when comparing groups to "Irradiation + Distilled Water Group" (b) or.

- $\mathrm{c} * \mathrm{P}<0.05 ; \mathrm{c}^{* * \mathrm{P}}<0.01 ; \mathrm{c}^{* * * \mathrm{P}}<0.001$ : when comparing groups to "Irradiation + Vitamin E and Lipoïc Acid Group" (c).

\subsubsection{Reduced Glutathione (GSH)}

$\gamma$-radiation and AGE intake have led to a significant decrease $(\mathrm{P}<0.001)$ in glutathione reduced levels in the group "Irradiation + Distilled Water" in order of 33.16\% (59.26 \pm 3.02 Vs $88.67 \pm 2.37 \mu \mathrm{mol} / \mathrm{mg}$ of tissue) and a significant increase $(\mathrm{P}<0.001)$ in the group "Irradiation $+25 \mathrm{mg} / \mathrm{kg} \mathrm{AGE"} \mathrm{in} \mathrm{the}$ range of $29.50 \%(114.83 \pm 2.49 \mathrm{Vs} 88.67 \pm 2.37 \mu \mathrm{mol} / \mathrm{mg}$ of tissue) compared to the negative control group "Sham Irradiation + Distilled Water" (Table 1). Among the irradiated groups, a significant increase $(\mathrm{P}<0.001)$ was observed in the groups "Irradiation $+25 \mathrm{mg} / \mathrm{kg}$ AGE" and "Irradiation +50 $\mathrm{mg} / \mathrm{kg}$ AGE" respectively, in order of $93.75 \%$ (114.83 \pm 2.49 Vs $59.26 \pm 3.02 \mu \mathrm{mol} / \mathrm{mg}$ of tissue) and $71.89 \%(101.87 \pm 6.10$ Vs $59.26 \pm 3.02 \mu \mathrm{mol} / \mathrm{mg}$ of tissue) when taking a look to the group "Irradiation + Distilled Water". In addition, compared to the positive control group ("Irradiation + Vitamin E and Lipoïc Acid"), a significant increase $(P<0.001)$ in glutathione reduced was observed in the group "Irradiation $+25 \mathrm{mg} / \mathrm{kg}$ AGE" in order of $56.26 \% \quad(114.83 \pm 2.49 \mathrm{Vs} \quad 73.49 \pm 3.60$ $\mu \mathrm{mol} / \mathrm{mg}$ of tissue) and of $38.63 \% \quad(101.87 \pm 6.10 \mathrm{Vs}$ $73.49 \pm 3.60 \mu \mathrm{mol} / \mathrm{mg}$ of tissue) in those of the group "Irradiation + $50 \mathrm{mg} / \mathrm{kg} \mathrm{AGE} \mathrm{".}$

\subsubsection{Superoxide Dismutase (SOD)}

From Table 1, it is clear that irradiation caused a significant increase $(\mathrm{P}<0.001)$ in SOD of about $37.77 \%$ $(91.62 \pm 0.33 \mathrm{Vs} 66.50 \pm 0.65 \mu \mathrm{mol} / \mathrm{mg}$ of protein) in the group "Irradiation + $25 \mathrm{mg} / \mathrm{kg} \mathrm{AGE"} \mathrm{and} \mathrm{a} \mathrm{significant} \mathrm{decrease} \mathrm{(P}$ $<0.001)$ in the range of $40.12 \%(39.82 \pm 0.39 \mathrm{Vs} 66.50 \pm 0.65$ $\mu \mathrm{mol} / \mathrm{mg}$ of protein) and $25.41 \%(49.60 \pm 0.37 \mathrm{Vs} 66.50 \pm 0.65$ $\mu \mathrm{mol} / \mathrm{mg}$ of protein) in groups "Irradiation + Distilled Water" and "Irradiation + Vitamin E and Lipoïc Acid" compared to the negative control group "Sham Irradiation + Distilled Water". A significant increase $(P<0.001)$ was observed in the groups "Irradiation $+25 \mathrm{mg} / \mathrm{kg}$ AGE" and "Irradiation + $50 \mathrm{mg} / \mathrm{kg}$ AGE" respectively, in order of $130.09 \%$ $(91.62 \pm 0.33 \mathrm{Vs} 39.82 \pm 0.39 \mu \mathrm{mol} / \mathrm{mg}$ of protein) and $87.39 \%$ $(74.62 \pm 0.41$ Vs $39.82 \pm 0.39 \mu \mathrm{mol} / \mathrm{mg}$ of protein) when comparing those groups with the group "Irradiation + Distilled Water". In addition, compared to the positive control group ("Irradiation + Vitamin E and Lipoïc Acid"), a significant increase $(\mathrm{P}<0.001)$ in SOD was observed in the group "Irradiation $+25 \mathrm{mg} / \mathrm{kg}$ AGE" in order of $84.72 \%$ $(91.62 \pm 0.33 \mathrm{Vs} 49.60 \pm 0.37 \mu \mathrm{mol} / \mathrm{mg}$ of protein) and of $50.44 \%$ (74.62 $\pm 0.41 \mathrm{Vs} 49.60 \pm 0.37 \mu \mathrm{mol} / \mathrm{mg}$ of protein) in those of the group "Irradiation + $50 \mathrm{mg} / \mathrm{kg}$ AGE ".

\subsubsection{Catalase (CAT)}

Irradiation and AGE intake have led to a significant decrease $(\mathrm{P}<0.01)$ in CAT level in the group "Irradiation + Distilled Water" in order of $41.66 \%(4.38 \pm 0.45 \mathrm{Vs} 7.51 \pm 0.50$ $\mu$ moles $\mathrm{H}_{2} \mathrm{O}_{2} /$ minute $/ \mathrm{mg}$ of protein) and a significant increase $(\mathrm{P}<0.05)$ in the group "Irradiation $+25 \mathrm{mg} / \mathrm{kg}$ AGE" in order of $31.53 \% \quad(9.88 \pm 0.75$ Vs $7.51 \pm 0.50 \mu$ moles $\mathrm{H}_{2} \mathrm{O}_{2} /$ minute/mg of protein) compared to the negative control group "Sham Irradiation + Distilled Water" (Table 1). When taking a look at the group "Irradiation + Distilled Water", a significant increase $(\mathrm{P}<0.001)$ was observed in the groups "Irradiation + $25 \mathrm{mg} / \mathrm{kg} \mathrm{AGE"} \mathrm{and} \mathrm{"Irradiation}+50 \mathrm{mg} / \mathrm{kg}$ AGE" respectively, in order of $125.46 \%(9.88 \pm 0.75 \mathrm{Vs}$ $4.38 \pm 0.45 \mu$ moles $\mathrm{H}_{2} \mathrm{O}_{2} /$ minute/mg of protein) and $98.73 \%$ $\left(8.71 \pm 0.60\right.$ Vs $4.38 \pm 0.45 \mu$ moles $\mathrm{H}_{2} \mathrm{O}_{2} /$ minute/mg of protein). In addition, compared to the positive control group ("Irradiation + Vitamin E and Lipoïc Acid"), a significant increase $(\mathrm{P}<0.001$ and $\mathrm{P}<0.05)$ in Catalase was observed in the group "Irradiation $+25 \mathrm{mg} / \mathrm{kg}$ AGE" in order of $58.50 \%$ (9.88 $\pm 0.75 \mathrm{Vs} 6.23 \pm 0.52 \mu$ moles $\mathrm{H}_{2} \mathrm{O}_{2} /$ minute/mg of protein) and of $39.71 \%(8.71 \pm 0.60 \mathrm{Vs} 6.23 \pm 0.52 \mu$ moles $\mathrm{H}_{2} \mathrm{O}_{2} /$ minute/mg of protein) in the group "Irradiation +50 mg / kg AGE " (Table 1).

\subsubsection{Nitrite $\left(\mathrm{NO}^{2-}\right)$}

In comparison with the to the negative control group "Sham Irradiation + Distilled Water" (Table 1), irradiation and AGE administration induced a significant increase in nitrite level $(\mathrm{P}$ $<0.05)$ in order of $40.97 \%(0.054 \pm 0.003 \mathrm{Vs} 0.038 \pm 0.001$ $\mu \mathrm{mol} / \mathrm{mL})$ in the group "Irradiation + Distilled Water" while a significant decrease $(\mathrm{P}<0.01)$ of about $48.33 \%(0.020 \pm 0.002$ Vs $0.038 \pm 0.001 \mu \mathrm{mol} / \mathrm{mL}$ ) occurred in the group "Irradiation + $25 \mathrm{mg} / \mathrm{kg}$ AGE" (Table 1). Furthermore, a significant decline in $\mathrm{N}^{2-}$ level $(\mathrm{P}<0.001)$ was observed in the animals irradiated and receiving $\mathrm{AGE}$ at doses of $25 \mathrm{mg} / \mathrm{kg}$ and 50 $\mathrm{mg} / \mathrm{kg}$ compared to those of "Irradiation + Distilled Water" group. This decrease was respectively in order of $63.35 \%$ $(0.020 \pm 0.002$ Vs $0.054 \pm 0.003 \mu \mathrm{mol} / \mathrm{mL})$ and $45.48 \%$ $(0.029 \pm 0.004 \mathrm{Vs} 0.054 \pm 0.003 \mu \mathrm{mol} / \mathrm{mL})$. Similarly, compared to the irradiated positive control group receiving Vitamin $\mathrm{E}$ and Lipoïc Acid, a significant decrease $(\mathrm{P}<0.001$ and $\mathrm{P}<$ 0.01 ) in Nitrite level was also observed in the groups "Irradiation + $25 \mathrm{mg} / \mathrm{kg} \mathrm{AGE"} \mathrm{and} \mathrm{"Irradiation} 50 \mathrm{mg} / \mathrm{kg}$ AGE" respectively in the range of $56.60 \%(0.020 \pm 0.002 \mathrm{Vs}$ $0.045 \pm 0.004 \mu \mathrm{mol} / \mathrm{mL})$ and $35.45 \% \quad(0.029 \pm 0.004 \quad \mathrm{Vs}$ $0.045 \pm 0.004 \mu \mathrm{mol} / \mathrm{mL}$ ).

\subsubsection{Malondialdehyde (MDA)}

The effects of radiation and AGE intake on MDA levels are shown in Table 1. Comparison of the groups with the negative control "Sham Irradiation + Distilled Water" revealed a significant increase of MDA level $(\mathrm{P}<0.05)$ in order of $35.92 \% \quad(0.33 \pm 0.03 \mathrm{Vs} \quad 0.24 \pm 0.01 \mu \mathrm{mol} / \mathrm{mg}$ of tissue) in the group "Irradiation + Distilled Water" while a significant decrease $(\mathrm{P}<0.05)$ of about $42.47 \%(0.14 \pm 0.01$ 
Vs $0.24 \pm 0.01 \mu \mathrm{mol} / \mathrm{mg}$ of tissue) occurred in the group "Irradiation $+25 \mathrm{mg} / \mathrm{kg}$ AGE". Furthermore, a significant decline in MDA level $(\mathrm{P}<0.001)$ was observed in the animals irradiated and receiving AGE at doses of $25 \mathrm{mg} / \mathrm{kg}$ and $50 \mathrm{mg} / \mathrm{kg}$ compared to those of "Irradiation + Distilled Water" group. This decrease was respectively in order of $57.68 \%(0.14 \pm 0.01 \mathrm{Vs} 0.33 \pm 0.03 \mu \mathrm{mol} / \mathrm{mg}$ of tissue $)$ and $44.49 \% \quad(0.18 \pm 0.02 \mathrm{Vs} \quad 0.33 \pm 0.03 \mu \mathrm{mol} / \mathrm{mg}$ of tissue $)$. Similarly, compared to the irradiated positive control group receiving Vitamin E and Lipoïc Acid, a significant decrease $(\mathrm{P}<0.001)$ in MDA level was also observed in the groups "Irradiation $+25 \mathrm{mg} / \mathrm{kg}$ AGE" in the range of $48.93 \%$ (0.14 $\pm 0.01 \mathrm{Vs} 0.27 \pm 0.04 \mu \mathrm{mol} / \mathrm{mg}$ of tissue).

\section{Discussion}

All types of ionizing radiation generate ions which can lead to the formation of free radicals and reactive oxygen species (ROS). Excess production of free radicals or decrease in antioxidants level leads to oxidative stress. It is a harmful process that induces damage to cell structures, lipids, proteins, RNA and DNA which leads to number of diseases [25]. The use of plants, natural products are thoughts to be beneficial in protecting against radiation-induced damage, they are less toxic compared to synthetic compounds used at their optimum protective dose levels [26-27] thence the interests has always existed in development of potential drug of plant origin, been a good sources of potent but non-toxic radioprotectors [28]. The investigations made; revealed AGE ameliorates the toxic side effects of different substances through its antioxidant and radical scavenging activities [29]. The aim of this study was to investigate the possible protective effect of AGE against the disturbances induced by radiations in rat's liver.

Serum proteins are synthesized and secreted by several cell types depending on the nature of the individual serum protein [30]. An important function of serum protein is the maintenance of the normal distribution of body water by controlling the osmotic balance between the circulating blood and the membrane of tissues, and the transport of lipids, hormones and inorganic materials [31]. The results obtained in this work showed that, there is significant decrease in serum total proteins post irradiation. The decrease in serum protein in irradiated rats might be the result of damage of vital biological processes or due to changes in the permeability of liver, kidney and other tissues resulting in leakage of protein via the kidney [32-35]. The decrease in blood total protein might be due to the slow rate in synthesis of all protein fractions after irradiation [36-37]. This decrease coincides with the decrease in serum total protein reported by other workers in irradiated rats, which may be due to radiation damage to the liver [38]. The decrease in protein in irradiated rats might be the result of either damage of biological membranes or to changes in the permeability of the liver [39-41]. Several investigations indicated that exposure to radiation increases free radical activity which is considered to be the primary cause of damaging effects.
Radiation induced lipid peroxidation, reduce protein synthesis and cause disturbances in the enzyme activity of the liver [42].

In the present study, there was a decrease in contents of total proteins in serum of rats irradiated with gamma radiation, indicating liver injury $[1,43]$. These results are in accordance with other studies using high-energy radiation from cobalt source [44]. Therefore, it is suggested that oxidative stress as a result of gamma-irradiation is linked to the organ damage following exposure to ionizing radiation. Kempner explained that this decrease in proteins level due to gamma radiation can damage or inactivate proteins by two different mechanisms. First, it can rupture the covalent bonds in target protein molecules as a direct result of a photon depositing energy into the molecule. Second, it can act indirectly, link with a water molecule, producing free radicals and other non-radical reactive oxygen species that are in turn responsible for most $(99.9 \%)$ of the protein damage [31, 45].

Oral administration of AGE one hour after irradiation on day 1 after acclimatization has caused a significant increase in serum total proteins in AGE groups. The increase was more important in "Irradiation $+25 \mathrm{mg} / \mathrm{kg}$ AGE" group than in "Irradiation+50 $\mathrm{mg} / \mathrm{kg} \mathrm{AGE"} \mathrm{group} \mathrm{or} \mathrm{"Irradiation} \mathrm{+}$ Vitamin E and Lipoïc Acid". AGE and SAC were shown to scavenge ROS [10] and to inhibit lipid peroxide formation in several studies $[14,46]$. These antioxidant effects can be due to allixin, SAC, SMAC and diallyl polysulfides, whose radical-scavenging action increased with the number of sulfur atoms [47]. Or, due to to N-fructosyl arginine and $\mathrm{N}$ fructosyl glutamate which showed antioxidant effects by spin resonance spectroscopy [12].

Gamma radiation induced an increase in ALP activity in liver tissue on the first and seventh post-exposure day [48]. This may be attributed to the possible release of this enzyme from different tissues associated with the obstruction of the blood stream to the liver [49]. The function and integrity of liver cells are well evaluated with transaminases activities [50], thus change in tissue permeability due to irradiation could enhance the release of transaminases enzymes from their subcellular sites of production to extracellular process and consequently to blood circulation [51]. Radiation exposure caused damage to the cell membrane that increased the ALP activity. This change in ALP activity might be due to radiation induced changes in the amino acid residue and catalytic activity of ALP [52] and due to destruction of this enzyme by radiation [53]. Furthermore, liver responds to hepatobiliary injury by synthetizing more enzymes which inter the circulation, raising the enzyme level in serum [54].

In the present study, the rats irradiated showed elevation of serum levels of ALT, AST, ALP and Bilirubin (Total Serum Bilirubin, Direct Bilirubin and Unconjugated Bilirubin) as compared with saline control group. In agree with our results, El-Kafif et al. explained that this increase may be ascribed to the irradiation-induced damage to hepatic parenchymal cells as well as extra hepatic tissues with a subsequent release of the enzymes into the blood stream [39]. It may also be attributed to the structural damage in spleen, lymphnodes and 
mature lymphocytes [55]. Moreover, the destruction of erythrocytes due to ionizing radiation and the release of their enzymes cannot be excluded as a causative factor for the rise in these enzymes [56]. The increased activity of serum ALP by gamma radiation agrees with Tabachnick et al. who attributed it to the enzyme release from the tissues to the blood stream or to liver disturbances [57], particularly due to defects in cell membrane permeability [58]. The variation in transaminases activities may be due to certain damage in some tissue like heart, liver, kidney and skeletal muscles. Fahim et al. mentioned that whole body gamma radiation of rats showed significant changes in the activities of transaminases which are dependent on the time lapses after irradiation and the type of tissue containing the enzyme [59]. These results may be attributed to the state of hypoxia of parenchyma for contracting fibrous tissue and the increased permeability of hepatic cell membrane due to irradiation exposure with release of ALT enzyme to circulation. The elevation in the serum activity of ALT indicates lesions in the liver cells [60]. It is also a sign of liver parenchymal cell destruction induced by whole body gamma radiation [61].

The clinical and diagnostic values associated with changes in blood enzymes concentrations such as AST, ALT, ALP and bilirubin have long been recognized [62]. Increased levels of these diagnostic markers of hepatic function in irradiated rats are implicative of the degree of hepatocellular dysfunction caused by the radiation [61]. The increase in the levels of serum bilirubin reflected the depth of jaundice and the increase in transaminases was the clear indication of cellular leakage and loss of functional integrity of the cell membrane [63]. Omran et al. revealed that significant elevation in AST, ALT, ALP and bilirubin were recorded post exposed to gamma-irradiation which reflects detectable changes in liver functions [64]. Such elevation was in agreement with Hassan et al. [65]. They reported that this elevation is directly due by interaction of cellular membranes with gamma-rays or through an action of free radicals produced by this radiation.

Oral administration of AGE one hour after irradiation on day 1 after acclimatization significantly reduced radiation toxic effect on serum levels of AST, ALT, ALP and Bilirubin (Total Serum Bilirubin, Direct Bilirubin and Unconjugated Bilirubin) compared to untreated rats. The reduction was significant in groups receiving AGE at a dosage of $25 \mathrm{mg} / \mathrm{kg}$ compare to those receiving it at a dosage of $50 \mathrm{mg} / \mathrm{kg}$ or to those receiving Vitamin E and Lipoïc Acid after irradiation. This reduction of the liver enzymes following AGE intake in the serum levels of AST and ALT was also noticed by other authors [66-68] then Nada and Hawas observed it as well with the administration of other herbal plants [69]. According to Pradeep et al., free radical induced oxidative damage in the liver but the antioxidants of AGE decrease the lowering of liver enzymes by stabilizing the membrane permeability and reducing the leakage of enzymes into the blood [70]. Hepatoprotective effect also belongs to Garlic properties [71-72] and AGE protects the liver as well by benzopyrene or benzo(a) pyrene and aflatoxin $\mathrm{B}_{1}$ by the means of SAC and SAMC [73-75].
Ionizing radiations produced peroxidation of lipids leading to structural and functional damage to cellular membranous molecules directly by transferring energy or indirectly by generation of oxygen derived free radical $(\mathrm{OH})$, superoxide $\left(\mathrm{O}_{2}{ }^{-}\right)$and nitric oxide (NO) which are the predominant cellular free radicals [76-77]. Oxidative stress leads to over production of $\mathrm{NO}$, which readily reacts with superoxide to form peroxynitrite $\left(\mathrm{ONOO}^{-}\right)$and peroxynitrous acid which they can initiate lipid peroxidation [78]. Under normal conditions, the inherent defense system, including the enzymes superoxide dismutase, which dismutates superoxide; catalase and glutathione peroxidase, which destroy toxic peroxides, and small molecules including glutathione, protects against oxidative damage. Excessive liver damage and oxidative stress caused by $\gamma$-radiation might be responsible for the depletion of GSH [79-81]. Irradiation has been reported to cause renal GSH depletion and lipid peroxides accumulation in different organs [82-84]. It was found that the level of elevation in lipid peroxidation after irradiation is in proportion to radiation dose and elapsed time [85]. Moreover, the formation of lipid peroxidation ultimately would alter the composition of the glomerular basement membrane [86]. Evidence of radiation induced organs injury via a mechanism of oxidative stress caused by increased MDA and nitrite, reduced GSH levels and decreased activity of CAT, SOD were demonstrated by various studies [87-91]. Such oxidative stress was mediated through the generation of ROS that induced disturbance of membrane permeability and severe cell damage [92-93].

In the present study, radiation induced higher MDA level and nitrite, while decreasing SOD, CAT activities and GSH level in the homogenate of rat liver tissue. Increase MDA level enhanced the lipid peroxidation and increased ROS production with subsequent disturbance of membrane function and integrity [94]. These results are in accordance with those of Halliwell, and Gutterige, [95] who observed a significant decrease in SOD and catalase activity after exposure to irradiation due to the excess production of hydroxyl radicals and other reactive oxygen species. SOD is an important endogenous antioxidant enzyme which acts as the first line defense system against ROS and converts the superoxide radicals to $\mathrm{H}_{2} \mathrm{O}_{2}$. Glutathione peroxidase present in the cytoplasm of the cells removes $\mathrm{H}_{2} \mathrm{O}_{2}$ by coupling its reduction to $\mathrm{H}_{2} \mathrm{O}$ with oxidation of $\mathrm{GSH}$. Glutathione reductase regenerates GSH from oxidized glutathione in the presence of NADPH. GSH is a tripeptide and a powerful antioxidant present within the cytosol of cells and is the major intracellular non protein thiol compound. SH groups present in $\mathrm{GSH}$ react with $\mathrm{H}_{2} \mathrm{O}_{2}$ and the $\mathrm{OH} \bullet$ radical and prevent tissue damage and GSH is also capable of scavenging ROS directly or enzymatically via glutathione peroxidase [96]. The decrement of GSH level would be attributed to the decreased activity of glucose-6- phosphate dehydrogenase (G-6-PD) that generates reduced NADPH which generates GSH from oxidized glutathione (GSSG) under the effect glutathione reductase [97]. Moreover, Dahm et al. attributed the decrease in liver GSH content to the 
inhibition of GSH efflux across hepatocytes membranes [98]. The presence of adequate amount of GSH, SOD and catalase minimize lipids peroxidation [92].

In several studies, natural products with antioxidants components were used to protect against oxidative stress induced by radiations [99-101]. Capasso, Ana et al., revealed AGE exhibited potent antioxidant and free radical scavenging activities [27-28].

Administration of AGE, one hour after irradiation on day 1 after acclimatization induced significant increase in CAT, SOD and GSH activities accompanied with significant decrease in MDA level and nitrite in radiation-treated rat's liver. These effects have been more pronounced with the lower dose of AGE $(25 \mathrm{mg} / \mathrm{kg})$ than with the higher $(50$ $\mathrm{mg} / \mathrm{kg}$ ) or the administration of Vitamin E and Lipoïc Acid. Suggesting in accordance with Khalid S Al-Numair that garlic extracts may have a beneficial effect on antioxidant status by improving antioxidant metabolic indices in rat's plasma [102]. This positive effect can be explained by the presence of S-allyl cysteine, S-allyl mercaptocyteine, allicin, and selenium; compounds responsible for the antioxidant activity of AGE [27]. In vivo, S-allyl cysteine significantly increased antioxidant activities and reduced as well lipid peroxidation widespread [103]. Thus, AGE ameliorates lipid peroxidation [104] and acts as a protective mechanism against oxidative damages of rat liver tissues induced by acute radiation [105-106].

In accordance with this study, significant increase in CAT, SOD and GSH activities were reported in animals treated with AGE as well as significant decrease in MDA and nitrite levels $[68,103,107]$. Garlic has been reported to modulate lipid peroxidation levels and enhance the status of antioxidant [106, 108-109]. It also elevates the levels of SOD, GSH-Px and Catalase [110-111]. The presence of non-enzymatic antioxidants such as selenium, copper metals, vitamin $\mathrm{C}$ and organosulphur compounds are also responsible for the beneficial effects of garlic; according to Prasad et al. [112]. AGE increases cellular glutathione and other ROS scavenging enzymes in several cells including liver and mammary tissue due to organosulfur components and phenolic compounds $[110,113]$. Thus, AGE radioprotective effects [114] relies on its capacity to scavenge free radicals [110] and enhance scavenging systems in the cell, including glutathione, SOD, catalase and glutathione peroxidase $[110,115]$.

\section{Conclusion}

From the present study, it can be concluded that $\gamma$ radiation induced damages in rat's liver through oxidative stress and lipid peroxidation but these changes are being improved by the intake of AGE, suggesting its radioprotective efficacy. Furthermore, the study revealed that the radioprotective effects of AGE was more pronounced with the lower dose of AGE $(25 \mathrm{mg} / \mathrm{kg})$ than with the higher $(50 \mathrm{mg} / \mathrm{kg})$ and the power of AGE was greater than the one of the positive control group Vitamin E and Lipoïc Acid concerning radio-protective properties.

\section{References}

[1] El-Missiry, M. A.; Fayed, T. A.; El-Sawy, M. R. and ElSayed, A. A. Ameliorative effect of melatonin against gammairradiation induced oxidative stress and tissue injury. Ecotoxicol. Environ. Saf. 2007; 66(2): 278-86.

[2] Abady M. M.; Zahran, A. M. and Mansour, S. Biochemical studies on rosemary extracts as antioxidants in irradiated rats. Egypt. J. Rad. Sci. Applic. 2003; 16(1): 139-151.

[3] Srinivasan M.; Sudheer, A. R.; Pillai, K. R.; Kumar, P. R.; Sudhakaran, P. R. and Menon, V. P. Lycopene as anatural protector against gamma-radiation induced DNA damage, lipid peroxidation and antioxidant status in primary culture of isolated rat hepatocytes in vitro. Biochim. Biophys. Acta. 2007; 1770(4): 659-65.

[4] Saada, H. N. and Azab, Kh. Sh. Role of lycopene in recovery of radiation induced injury to mammalian cellular organelle. Pharmazie. 2001; 56(3): 239-41.

[5] Patt H M, Tyree E B, Straube R L and Smith D E. Cysteine protection against X-irradiation. Science. 1949; 110, 213-214.

[6] Sweeney T R. A Survey of Compounds from the Antiradiation Drug Development Program of the U. S. Army Medical Research and Development Command. Publication 308-318, U. S. Government Printing Office, Washington, DC, 1979.

[7] Sen, S.; Chakraborty, R.; Sridhar, C.; Reddy, Y. and Biplab, De. Free radicals, antioxidants, diseases and phytomedicine: current status and future prospect. International Journal of Pharmaceutical Sciences Review and Research. 2010; 3(1): 91-100.

[8] Kong Ah-Ng T., Yu R., Chen C., Mandlekar S and Primiano T. Signal transduction events elicited by natural products: Role of MAPK and caspase pathways in homeostatic response and induction of apoptosis. Arch. Pharm. Res. 2000; 23, 1-16.

[9] Ahmed R. S., Seth V. and Banerjee B. D. Influence of dietary ginger (Zingiber officinales Rosc) on antioxidant defense system in rat: Comparison with ascorbic acid. Indian J. Exp. Biol. 2000: 38, 604-606.

[10] Singh I, Sharma A, Nunia V and Goyal P K. Radioprotection of Swiss albino mice by Emblica officinalis. Phytother., Res. 2005; 19: 444-446. doi: 10.1002/ptr.1600

[11] Naziroglu, M. protective role of intraperitoneally administered vitamin $\mathrm{E}$ and selenium on the antioxidative defense mechanisms in rats with diabetes induced by streptozatocin. 2001; 79: 149-159.

[12] Amagase H, Petesch B L, Matsuura H, Kasuga S and Itakura Y. "Intake of garlic and its bioactive components," Journal of Nutrition, vol. 131, supplements. 2001; 3: 955-962.

[13] Moriguchi T, Saito H, Nishiyama N. Anti-aging effect of aged garlic extract in the inbred brain atrophy mouse model. Clin. Exp. Pharmacol. Physiol. 1997; 24: 235-42.

[14] Balamash K, Albar O, Wang Q and Ahmed N: Effect of Kyolic ${ }^{\circledR}$ aged garlic extract on glycaemia, lipidaemia and oxidative stress in patients with type 2 diabetes mellitus. Journal of Diabetes Research and Clinical Metabolism. 2012, 1:p.18. 
[15] EEC: Council Directive 86/609/EEC of 24 November 1986 on the approximation of laws, regulations and administrative provisions of the Member States regarding the protection of animals used for experimental and other scientific purposes. Official Journal of the European Communities. 1986; L358: $1-29$.

[16] Kaplan A. Aspartate aminotransferase. Clin Chem The VC Mosby Co. St Louis. Toronto. Princeton, 1984. p. 1112-116.

[17] Prahlad K. V., Conaway C. H. Alkaline Phosphatase Activity in the Rat Uterus. J. Embryol. exp. Morph. 1961, 9 (4): 59908 .

[18] Gornall A. G, Bardawill C. J, David M. M, Determination of serum proteins by means of biuret reactions. J. Biol, Chem. 1949; 177: 751-766.

[19] Balistreri, W. F. and Shaw, L. M. Liver function. In: fundamentals of clinical chemistry. $n$ Teitz, N. W. (ed.). $3^{\text {rd }}$ ed. W. B. Saunders company, Philadelphia. 1987, 729-760.

[20] Ellman, G. L. Tissue sulfhydryl groups. Arch. Biochem. Biophys. 1959; 82: 70-7.

[21] Misra HP, Fridovich I. The role of superoxide anion in the autoxidation of epinephrine and a simple assay for superoxide dismutase. J Biol Chem. 1972; 247(10): 3170-5.

[22] Sinha KA, Colorimetric essay of catalase. Analyze Biochemistry, 1972, 47: p.389-94.

[23] Slack PT,. Analytical methods manual, British food Manufacturing industries. Research Association, Leatherland, 1987.

[24] Wilbur Km, Bernheim F, Shapiro OW. The thiobarbituric acid reagent as a test for the oxidation of unsaturated fatty acids by various agents. Arch. Biochem. 1949; 24(2): 305-313.

[25] Valko, M.; Leibfritz, D.; Moncol, J.; Cronin, MT.; Mazur, M. and Telser, J. Free radicals and antioxidants in normal physiological functions and human disease, The International Journal of Biochemistry \& Cell Biology. 2007; 39, 44-84.

[26] Bhatia AL, Manda K, Patni S, Sharma AL. Prophylactic action of linseed (Linum usitatissimum) oil against cyclophosphamide-induced oxidative stress in mouse brain. $J$ Med Food. 2006; 9(2): 261-4.

[27] Sharma M. K. and Sisodia R. $\beta$-carotene against Radiationinduced oxidative stress in mice brain. Asian J. of Exp. Sci. 2000; 14: 43-44.

[28] Blokhina O, Virolainen E, Fagerstedt KV. Antioxidants, oxidative damage and oxygen deprivation stress: a review. Ann Bot. 2003; 91: 179-94.

[29] Ashraf Y. Nasr. Protective effect of aged garlic extract against the oxidative stress induced by cisplatin on blood cells parameters and hepatic antioxidant enzymes in rats. Toxicology Reports. 2014; 1: 682-691.

[30] Harper, H. A.; Rodwell, V. W. and Mayes P. A. In review of physiological chemistery. $18^{\text {th }}$ ed. Lange Medical Publication. Marzen Company Limited. Los Altos. California. USA. 328, 1977.

[31] Maha Mahmoud Ali Mohammed. The Possible Protective Role of Foeniculum vulgare Mill. Against Radiation-Induced Certain Biochemical Changes in Albino Rats. Master Degree of Science in Zoology, Faculty of Science, Beni-Suef University, 2010.
[32] Saada, B. N. Studies on the biochemical changes induced by irradiation with special reference to some protecting drug. $M$. Sc. Thesis, Fac. of Sci, Ain Sham Univ, 1982.

[33] Roushdy, H. M.; El-Huseini, M. and Saleh, F. Effect of whole body gamma irradiation and/ or dietary protein deficiency on the levels of plasma non-protein nitrogen and amino acids, plasma and urinary ammonia and urea in desert rodent and albino rats. Egypt. J. Rad. Sci. Applic. 1984; 1(2): 157.

[34] Srinivasan, M. N.; Basu, S. K. and Shose, A. Effect of chemical radioprotectors on serum proteins of rats exposed to gamma irradiation. Ind. J. Exp. Biol. 1985; 23(9): 490-2.

[35] Haggag, A. M.; El-Beih, N. M. and Mangood, S. A. In vivo internal decontamination of $134 \mathrm{Cs}$ and $60 \mathrm{Co}$ from male albino rats. Egypt. J. Rad. Sci. Applic.. 2008; 21(2): 531-546.

[36] Reuter, A. M.; Gerber, G. B.; Kennes, F. and Remy-Defraigne, J. Catabolism of serum proteins after x-irradiation. Rad. Res. 1967; 30(4): 725-38.

[37] Takhtayev, T. M. and Tadzh, T. Changes in serum proteins after prolonged irradiation and treatment with leukocytin. Gas. Med. Inst. 1972; 97: 125.

[38] Kafafy, Y. H. and Ashry, O. Antioxidative potential of parsley on gamma irradiated rats. Egypt J. Rad. Sci. Applic. 2001; 14: $25-42$.

[39] El-Kafif, M.; Ragab, M.; El-Dawy, H. and Tawfik, S. Effect of ttaurine treatment on some biochemical parameters in gamma irradiated mice. Environ. Sci. 2003; 6(2): 393-401.

[40] Roushdy, H. M.; El-Hussaini, M. and Saleh, F. Effect of wholebody gamma-irradiation and/or dietary protein defeciency on levels of plasma non-protein-nitrogen and amino acids in desert rodents and albino rats. Egypt J. Rad. Sci. Applic. 1989; 1: 156-166.

[41] Samarth, R. M.; Goyal, P. K. and Kumar, A. Modulatory effect of Mentha piperitia (Linn.) on serum phophatases activity in Swiss albino mice against gamm-irradiation. Ind. J. Exp. Biol. 2001; 39(5): 479-82.

[42] Kadiiska, M.; Gladen, B.; Baired, D.; Dikolova, A.; Sohal, R.; Hatch, G.; Jones, D.; Mason, R. and Barrett, J. Biomarkers ofoxidative stress study: are plasma antioxidant markers of CCL4 poisoning? Free. Rad. Biol. Med. 2000; 28(6): 838-45.

[43] Ali, M. M.; Noaman, E.; Kamal, Sh.; Soliman, S. and Ismail, D. A. Role of germanium L-cysteine $\alpha$-tocopherol complex as stimulator of some antioxidant defense system in gamma irradiated rats. Acta. Pharm, 2007; 57: 1-12.

[44] Bhatia, A. L., Manda, K. Study on pre-treatment of melatonin against radiation-induced oxidative stress in mice. Environ. Toxicol. Pharmacol. 18. 2004; (1): 13-20.

[45] Kempner, E. S. Effects of high-energy electrons and gamma rays directly on protein molecules. J. Pharm. Sci. 2001; 90(10): 1637-1646.

[46] Block E. The chemistry of garlic and onions. Sci Am. 1995; 252: 94-99.

[47] Hahn G. "History, folk medicine, and legendary uses of garlic," in Garlic: The Science and Therapeutic Application of Allium Sativum L and Related Species, H. P. Koch and L. D. Lawson, Eds., pp. 1-24, Williams \& Wilkins, Baltimore, Md, USA, 1996. 
[48] Sanaa A. Ali, Lila M. Fadda, Hesham Elebiary, Miada Soliman. Evaluation of the radioprotective action of anserine along with zinc in albino rats exposed to gammaradiation. Journal of Applied Pharmaceutical Science. 2012; 2(04): 115-122.

[49] Khamis F, Roushdy Hm. Synergistic radio-protective action of imidazole and serotonin on serum and liver enzymes in rats. Arab J Sci App. 1991; 24: 19-36.

[50] Adaramoye O. A., Osaimoje D. O., Akinsanya A. M., Nneji C. M., Fafunso M. A., Ademowo O. G. Changes in antioxidant status and biochemical indices after acute administration of artemether, artemether-lumefantrine and halofantrine in rats. J. Compil. Basic Clin. Pharmacol. Toxicol. 2008; 102: 412-418.

[51] Saad, T. M. M. and El Masry, F. S. Antioxidant activity of lycopene extracted from tomato pomace toward gamma irradiation hazardsin male albino rats. Isotope. Rad. Res. 2005; 37(4): 937-946.

[52] Kumar, M.; Sharma, M.; Saxena, P. and Kumar, A. Radioprotective effect of panax gensing on the phosphatases and lipid peroxidation level in testis of Swiss albino mice. Biol. Pharm. Bull. 2003; 26(3): 308-312.

[53] Abdel-Fattah, K. I.; El-Sayed, N. M.; Abou-Safi, H. M. and Hussain, A. H. The early alterations in some enzymatic activity, blood glucose and liver glycogen levels induced by atropine injection and whole body irradiation of rats. Egypt $J$. Rad. Sci. Applic. 1999; 12(2): 37-50.

[54] Moss, D. W.; Henderson, A. R. and Kachmar, J. F. Enzymes In: Fundamentals of clinical chemistry $3^{\text {rd }}$ ed n. Tietz, NW Ed. Philadelphia, WB Saunders Company. 1987; 346-421.

[55] Albaum, H. C. Serum enzymes following whole body radiation in the rabbit. Rad. Res. 1960; 12: 186-194.

[56] Azab, Kh.; Saada, H. and Said, O. The action of long term treatment with coenzyme Q10 in minimizing radiationinduced damage. Arab. J. Nucl. Sci. Applic. 2001; 34(1): 283289.

[57] Tabachnick, J.; Perlish, J. S.; Chang, L. F. and Freed, R. M. Enzymatic changes in beta-irradiated epidermis of Guenea pigs: acid and alkaline phosphatase and inorganic pyrophosphatase. Rad. Res. 1967; 32(2): 293-308.

[58] El-Missiry, M. A.; Roushdy, H. M.; Fayed, T. A. and Shehata, G. Role of bone marrow treatment for acute gamma radiationinduced changes in rats. J. Union. Arab. Biol. 1998; 10: $359-370$.

[59] Fahim, F.; Roushdy, H.; Yousri, R. and Abady, M. Some biochemical aspects of the protective of strontium chloride on gamma irradiated rats. Biometals. 1993; 6(3): 163-70.

[60] El-Sharaky A S, Newairy A A, Kamel M A, Eweda S M. Protective effect of ginger extract against bromobenzeneinduced hepatotoxicity in male rats. Food Chem. Toxicol. 2009; 47: 1584-1590.

[61] Mohammed M M A. The Possible Protective Role of Foeniculum vulgare Mill. Against Radiation-Induced Certain Biochemical Changes in Albino Rats. Master Degree of Science, Faculty of Science, Beni-Suef University, 2010.

[62] Martin P and Freidman L S, Kaffee E B, ed., Handbook of liver disease. Philadelphia, Churchill Livingstone. 1998; pp 1.
[63] Saraswat B, Visen P K, Patnaik G K And Dhawan B N. Anticholestatic effect of picroliv, active hepatoprotective principles or princilple of Picrohiza kurrooa, against carbon tetra chloride induced cholestasis. Ind. J. Exp. Boil. 1993; 3(4): 316-8.

[64] Omran M F, Abouellela A M K and Shahian Y E. Amifostine (WR2721) drug controls radiation induced damage inrats. Egypt. J. Rad. Sci. Applic. 2009; 22(2): 397-411.

[65] Hassan S, Abu-Gahadeer A and Osman S. Vitamins B and/or folic acid restoring the haematopioetic activity in irradiated rats. Egypt. J. Rad. Sci. Applic. 1996; 9(1): 67-78.

[66] Padalko E, Kozlova I, Leonova. Protective efficacy of garlic on cadmium induced oxidative stress in young and adult rats. Oxid. Antioxid. Med. Sci. 2012; 1(2): 101-109.

[67] Sharma A, Sharma V, Kansal L. Amelioration of lead-induced hepatotoxicity by Allium sativum extracts in Swiss albino mice. Libyan J. Med. 2010. 5: 4621.

[68] Alkreathy H, Zoheir A D, Nessar A, Mark S, Soad S A, Osman A M., Aged garlic extract protects against doxorubicin-induced cardiotoxicity in rats. Food Chem. Toxicol. 2010; 48: 951-956.

[69] Pradeep K, Mohan C V R, Gobianand K, Karthikeyan S. Silymarin modulates the oxidant-antioxidant imbalance during diethylni-trosamine induced oxidative stress in rats. Eur. J. Pharmacol. 2007; 560: 110-116.

[70] Nada A S, Hawas A M. Rhubarb extract ameliorates some biochemical disorders induced by gamma irradiation in male rats. J. Rad. Res. Appl. Sci. 2012; 5(2): 393-408.

[71] Horie T, Murayama T, Mishima T, Fumiyaki I, Minamide Y, Fuwa T, Awaxu S. Protection of liver microsomal membranes from lipid peroxidation by garlic extract. Planta Med. 1989; 55: p. 506-8.

[72] Agarwal K C. Therapeutic action of garlic constituents. Medical Research Review. 1996; 16: 111-124.

[73] Tadi PP, Teel RW, Lau BHS. Organosulfur compounds of garlic modulate mutagenesis, metabolism and DNA binding of aflatoxin B1. Nutr. Cancer. 1991; 15: 87-95.

[74] Borek C. Molecular mechanisms in cancer induction and prevention. Environ. Health Perspect 1993; 101: 237-45.

[75] Borek C. Antioxidants and cancer. Sci. Med. 1997; 4: 51-62.

[76] Spitz D R, Azzam E I, Li J J and Guis D. Metabolic oxidation/reduction reactions and cellular responses to ionizing radiation: a unifying concept in stress response biology. Cancer and Metastasis Rev. 2004, 23(3-4): 311-322.

[77] Joshi R, Kamat J P and Mukherjee T. Free radical scavenging reactions antioxidant activity of embelin: Biochemical and pulse radiolytic studies. Chem. Biol. Interact. 2007; 167(2): 125-34.

[78] Millar T M. Peroxynitrite formation from the simultaneous reduction of nitrite and oxygen by xanthene oxidase. FEBS Lett. 2004; 562 (1-3): 129-133.

[79] Koc M, Taysi S, Buyukokuroglu M E and Bakan N. Melatonin protects rat liver against irradiation-induced oxidative injury. J. Rad. Res. 2003; 44(3): 211-5.

[80] Samarth R M and Kumar A. Radioprotection of Swiss albino mice by plant extract Mentha piperita (Linn). J. Rad. Res. 2003; 44(2): 101-9. 
[81] Bhatia A L and Jain M. Spinacia olleracea L. protectects against gamma radiations, a study on glutathione and lipid peroxidation in mouse liver. Phytomedicine. 2004; 11(7-8): 607-15.

[82] Siems W, Gartner C, Kranz D, Schneider T, Grune T, Schimke J, Gau S, Wege U and Gerber G. Long term effects of monthly low dose whole body gamma irradiation on the glutathione status and thiobarbituric acid-reactive substances in different organs of male wistar rats. Radiobiol. Radiother. (Berl.). 1990; 31(3): $257-236$.

[83] El-Habit O H, Saada H N, Azab K S, Abdel-Rahman M and El-Malah D F. The modifying effect of beta-carotene on gamma radiation-induced elevation of oxidative reactions and genotoxicity in male rats. Mudat. Res. 2000; 466(2): 179.

[84] Yanardag R, Blokent S and Kizer A. Protective effects of DL$\alpha$-tocopherol acetate and sodium selenate on the liver of rats exposed to gamma radiation. Biol. Trace. Elem. Res. 2001; 83(3): 263-273.

[85] Ueda T, Toyoshima Y, Kushihashi T, Hishida T and Yasuhara H. Effect of dimethyle sulphoxide pretreatment on activities of lipid peroxidation formation, superoxide dismutase and glutathione peroxidase in the mouse liver after whole-body irradiation. J. Toxicol. Sci. 1993; 18(4): 239-44.

[86] Haas M, Kerjaschki D and Mayer G. Lipid lowering therapy in memberaneous nephropathy. Kidney. Internat. Suppl. 1999; 56: $110-112$.

[87] Ramadan L A, Shouman S A, Sayed-Ahmed M M and ElHabit O H. Modulation of radiation-induced organs toxicity bycremophor-el in experimental animals. Pharmacol. Res. 2001; 43(2): 185-91.

[88] Pulpanova J, Kovarova $\mathrm{H}$ and Ledvina $\mathrm{M}$. Change in the reduced Glutathione concentration and the activity of glutathione reductase in some tissues of the rats gammairradiated after administration of cystamine. Radiobiol. Radiother. 1982; 23(1): 50-6.

[89] Osman S A A. Melatonin beosting antioxidant capacity for effective radiation protection in albino rat. Egypt. J. Med. Sci. 1996; 17(2): 281-295.

[90] El-Ghazaly M A and Ramadan L A. Alterations in some metabolic functions in albino rats after irradiation and possible role of thiola. J. Egypt. Soc. Toxicol. 1996; 16: 105-9.

[91] Rajapakse N, Kim M M, Mendis E and Kim S K. Inhibition of free radical-mediated oxidation of cellular biomolecules by carboxylated chitooligosaccharides. Bio-org. Med. Chem. 2007; 15(2): 997-1003.

[92] Saada H A, Azab Kh Sh, Said O Z, Mohamed M A and Abbady M M. Role of genesing in the control of radiation induced injury in rat erythrocyte. J. Egypt. Ger. Soc. Zool. 1999; 28: 191-9.

[93] Abu-Ghadeer A R M, Osman S A and Abbady M M. Garlic protects the glutathione redox cycle in irradiated rats. Egypt. J. Rad. Sci. Applic. 1999; 12(2): 15-26.

[94] Estuo N. Lipid peroxidation: physiological levels and dual biological effects. Free Radic. Biol. Med. 2009; 47 (5): 469484.

[95] Halliwell B and Gutterige J. Protection against oxidants in biological systems; the superoxide theory of oxygen toxicity.
In: Free Radicals in Biology and Medicine. 1989; 2nd ed., 86. Kindersley, London.

[96] Siems WG, Grune T and Esterbauer H. 4-hydroxynonenal formation during ischemia and reperfusion of rat smallintestine. Life Science. 1995; 57: 785-789.

[97] Rotruck J T, Pope A L, Ganther H, Awanson A B, Hoffeman D G and Hofckstra W G. Selenium: Biochemical role as a component of glutathione peroxides. Sci. 1979; 179: 588-590.

[98] Dahm L J, Bailie M B and Roth R A. Relationship between alpha-naphthylisothiocyanate-induced liver injury and elevations in hepatic non-protein sulfhydryl content. Biochem. Pharmacol. 1991; 42(6): 1189-94.

[99] Dharmendra K Maura, Thomas P A Devasagayam and Cherpall Krishnan K Nair. Some novel approaches for radioprotection and the beneficial effect of natural products. Indian journal of experimental Biolog. 2006; 44: 93-114.

[100] Zhao Y, Shen S, Ling B. Protection by EGCG of DNA from radiation damage. Chaye kexue. 1995; 15: 145-48.

[101] Piya Paul, Unnikrishnan M K and Nagappa A N. Phytochemicals as radioprotective agents-A Review. Indian Journal of Natural Products and Resources. 2011; 2 (2): 137150 .

[102] Khalid S. Al-Numair. Hypocholesteremic and Antioxidant Effects of Garlic (Allium sativum L.) Extract in Rats Fed High Cholesterol Diet. Pakistan Journal of Nutrition. 2009; 8(2): 161-166.

[103] Almaca G. Antioxidant effects of sulfur containing amino acids. Yon-sei Med. J. 45 (5) (2004) 776-788.

[104] Arivazhagan S, Balascnthil S and Nagini S. Chemopreventive potential of garlic and neem during gastric carcionogensis induced by $N$-methyl- $N$ '-nitro- $N$-nitrosoguanidine. Med. Sci. Res. 1999; 27: 209-212.

[105] Carmia Borek. Antioxidant Health Effects of Aged Garlic Extract. J. Nutr. 2001; 131(3) 1010-1015.

[106] Arivazhagan S, Balascnthil S and Nagini S. Garlic and neem leaf extracts enhance hepatic glutathione and glutationicdependent enzymes during $N$-methyl- $N$ '-nitro- $N$ nitrosoguanidine (MNNG)-induced gastric carcinogenesis in rats. Phytotherapy Res. 2000; 14: 291-293.

[107] Gorinstein S, Leontowicz H, Leontowicz M, Drzewiecki J, Naj-man K, Katrich E, Barasch D, Yamamoto K, Trakhtenberg S. Raw and boiled garlic enhances plasma antioxidant activity and improves plasma lipid metabolism in cholesterol-fed rats. Life Sci. 2006; 78: 655-663.

[108] Arivazhagan S, Balascnthil S and Nagini S. Modulatory effects of garlic and neem leaf extracts on circulatory lipid peroxides and antioxidants during $N$-methyl- $N$-nitro- $N$ nitrosogunidine-induced gastric carcinogensis. Med. Sci. Res. 1999; 27: 527-529.

[109] Balascnthil S, Arivazhagan S, Ramachandran C R and Nagini S. Effects of garlic on 7, 12-dimethylbenz [a] anthraceneinduced hamster buccal pouch carcinogenesis. Cancer Detection and Prevention. 1999; 23: 534-538.

[110] Wei Z, Lau B. Garlic inhibits free radical generation and augments antioxidant enzyme activity in vascular endothelial cells. Nutr. Res. 1998, 18: 61-70. 
[111] Pinto J T, Qiao C and Zing J. Effects of garlic thioallyl derivatives on growth, glutathione concentration and polyamine formation of human prostate carcinoma cells in culture. Am. J. Clin. Nutr. 1997; 66: 398-405.

[112] Prasad K, Laxdal V A, Yu M and Raney B L. Antioxidant activity of allicin and active principal in garlic. Mol. Cell. Biochem. 1995; 148: 183-189.

[113] Liu J, Lin X, Milner J. Dietary garlic powder increases glutathione content and glutathione S-transferase activity in rat liver and mammary tissues. FASEB J. 1992; 6: A3230.

[114] Lau BHS. Detoxifying, radioprotective and phagocyteenhancing effects of garlic. Int. Nutr. Rev. 1989; 9: 27-31.

[115] Geng Z, Lau BHS. Aged garlic extracts modulate glutathione redox cycle and superoxide dismutase activity in vascular endothelial cells. Phytother Res. 1997; 11: 54-6. 